\title{
A Detailed Chemical Kinetic Model for Ethanol Oxidation
}

\author{
N. Marinov
}

This paper was prepared for submittal to the

Western States Section/Combustion Institute Spring Meeting

Livermore, $C A$

April 14-15, 1997

April 1997

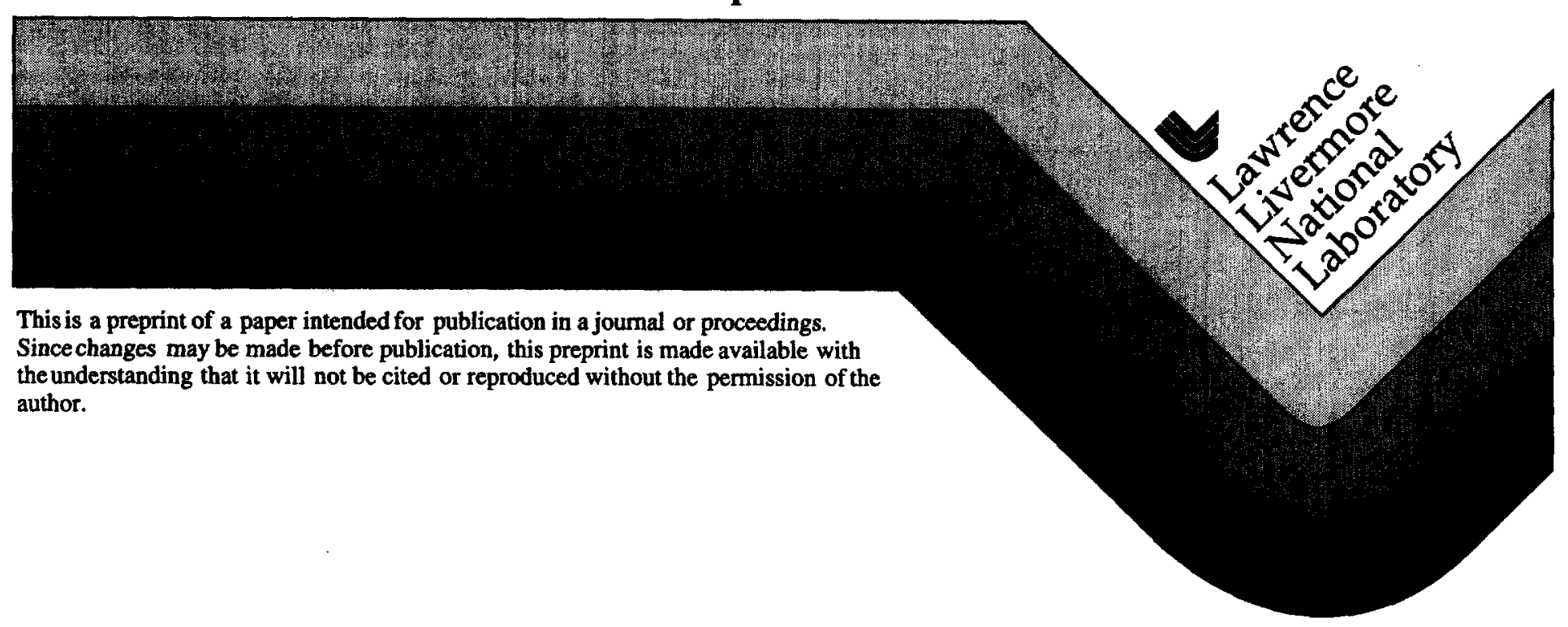




\section{DISCLAIMER}

This document was prepared as an account of work sponsored by an agency of the United States Government. Neither the United States Government nor the University of California nor any of their employees, makes any warranty, express or implied, or assumes any legal liability or responsibility for the accuracy, completeness, or usefulness of any information, apparatus, product, or process disclosed, or represents that its use would not infringe privately owned rights. Reference herein to any specific commercial product, process, or service by trade name, trademark, manufacturer, or otherwise, does not necessarily constitute or imply its endorsement, recommendation, or favoring by the United States Government or the University of California. The views and opinions of authors expressed herein do not necessarily state or reflect those of the United States Government or the University of California, and shall not be used for advertising or product endorsement purposes. 


\title{
A Detailed Chemical Kinetic Model for Ethanol Oxidation
}

\author{
Nick Marinov \\ Lawrence Livermore National Laboratory \\ P.O. Box 808 \\ Livermore, CA 94550 \\ Phone: (510) 424-5463 \\ Fax: (510) 422-2644 \\ E-mail: marinov@llnl.gov
}

Western States Section / Combustion Institute Sandia National Laboratory

Livermore, CA

Spring Meeting

14-15 April 1997 


\title{
A Detailed Chemical Kinetic Model for Ethanol Oxidation
}

\author{
Nick Marinov
}

Lawrence Livermore National Laboratory, P.O. Box 808, Livermore, CA 94550

\section{Abstract}

A detailed chemical kinetic model for ethanol oxidation has been developed and validated against a variety of experimental data sets. Laminar flame speed data obtained from a constant volume bomb, ignition delay data behind reflected shock waves, and ethanol oxidation product profiles from a turbulent flow reactor were used in this study. Very good agreement was found in modeling the data sets obtained from the three different experimental systems. The computational modeling results show that high temperature ethanol oxidation exhibits strong sensitivity to the fall-off kinetics of ethanol decomposition, branching ratio selection for $\mathrm{c} 2 \mathrm{~h} 5 \mathrm{oh}+\mathrm{oh}=$ products, and reactions involving the hydroperoxyl $\left(\mathrm{HO}_{2}\right)$ radical.

\section{Introduction}

In recent years, considerable interest in ethanol as a fuel extender, octane enhancer, oxygenate, and a neat fuel has increased dramatically because of concerns associated with conventional transportation fuels. The elimination of tetra-ethyl lead in gasoline during the mid-1980's and the 1990 Clean Air Act Amendments have required refinery operations to provide oxygenated gasoline in order to "fill the octane gap" and "reduce" carbon monoxide emissions and smog in the nation's most polluted areas. Currently, ethanol and methyl tert-butyl ether (MTBE) are the two oxygenated fuels most widely used in Federal and California reformulated gasoline, and winter oxygenated gasoline in the Western United States. Ethanol may be considered as the attractive oxygenate over MTBE as ethanol produced from biomass is a renewable fuel while MTBE requires isobutene, a fossil fuel, for synthesis, and ethanol has roughly double the oxygen content than MTBE on an oxygen to carbon basis. 
There are fundamental and practical reasons for examining the oxidation of ethanol. Approximately, 6 to 10 volume percent of reformulated gasoline consists of ethanol as required by current federal and state urban air quality standards. As regulations on pollutant emissions become stricter, the amount of oxygenated fuel like ethanol in gasoline could increase. Therefore, we need a full understanding of the reaction pathways by which ethanol is oxidized and of the pollutant species that it may produce. This understanding will allow industry and regulatory agencies to better evaluate the feasibility and relationship between the combustion process and pollutant emissions when using ethanol.

The objective of the current study is to develop and validate a detailed chemical kinetic model for ethanol combustion by comparison with ignition delay data, laminar flame speed data, and species profiles from ethanol oxidation in a flow reactor. Reaction pathway and sensitivity analysis are used to help identify those reactions and their accompanying rate constants that exhibit a strong influence on the ethanol oxidation process.

\section{Discussion on the Computational Models and the Detalled Chemical Kinetic Mechanism Development}

The modeling computations were performed using the CHEMKIN-II software [1]. The SENKIN code [2] was used to calculate ignition delays in a shock tube and to study fuel oxidation in a turbulent flow reactor. The ignition delay calculations were performed assuming a constant density gas behind the reflected shock, while the flow reactor calculations were performed at constant pressure with the additional constraint of using the experimentally measured temperature profile. The laminar flame speed calculations were performed using the PREMIX code [3] for freely propagating flames. These computations require the flame front to be one-dimensional with no heat loss to the surroundings. The central differencing technique was used in the numerical integration of the laminar flame speeds at $0.1 \mathrm{MPa}$, and for pressures greater than $0.1 \mathrm{MPa}$, the upwind differencing scheme was used. Thermal diffusion was included in the calculations.

The thermodynamic properties for the species used in this study were primarily obtained from the CHEMKIN thermodynamic database [4], and Burcat and McBride [5]. Thermodynamic properties for those species not found in the 
exists at elevated temperatures on the relative rates of $\mathrm{H}$-atom abstraction from these species. Furthermore, propane and methanol exhibit very similar $\mathrm{O}-\mathrm{H}$ and $\mathrm{C}-\mathrm{H}$ bond strengths as found in ethanol. We find the $\mathrm{O}-\mathrm{H}(104 \mathrm{kcal} / \mathrm{mol})$ and secondary $\mathrm{C}-\mathrm{H}(96-98 \mathrm{kcal} / \mathrm{mol})$ bond strengths in ethanol, as shown in the diagram below, to be very similiar to the $\mathrm{C}-\mathrm{H}(96-98 \mathrm{kcal} / \mathrm{mol})$ and $\mathrm{O}-\mathrm{H}$ $(104 \mathrm{kcal} / \mathrm{mol})$ bond strengths found in methanol while the primary (100kcal/mol)) and secondary $(98 \mathrm{kcal} / \mathrm{mol}) \mathrm{C}-\mathrm{H}$ bond strengths in propane are very similiar to that found in ethanol. The similarity in bond strengths between the model compounds and ethanol allows for a set of equations to be developed and solved using the relative rates of $\mathrm{H}$-atom abstraction found for each model compound and constrained by the overall reaction rate exhibited in the $\mathrm{H}$-atom abstraction process for ethanol. The reaction path degeneracy associated with the number $\mathrm{H}$-atoms available for abstraction between ethanol and the model compounds were included in the branching ratio calculations. The equations used in the branching ratio determination for the $\mathrm{C} 2 \mathrm{H} 5 \mathrm{OH}+\mathrm{X}=$ Products (where $\mathrm{X}=\mathrm{OH}, \mathrm{O}, \mathrm{H}, \mathrm{CH} 3$ ) reactions are shown below:

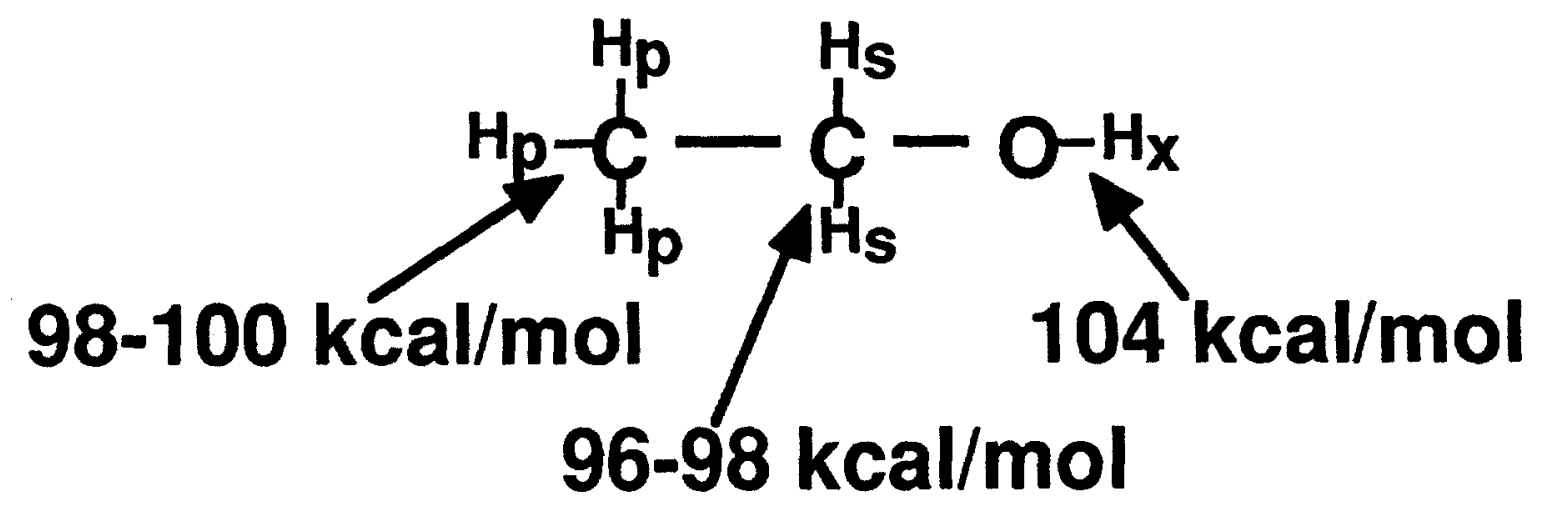

$$
\begin{aligned}
& K_{\mathbf{s}} / K_{\mathbf{x}}=R 1 \text { and } K_{p} / K_{s}=R 2 \text {, and } K_{\text {overall }}=K_{p}+K_{s}+K_{x} \\
& K p=\text { Koverall } R 2 /((1 / R 1)+R 2+1) \\
& K_{s}=K_{\text {overall }} /((1 / R 1)+R 2+1) \\
& K_{\mathbf{X}}=(\text { Koverall / R1) } /((\mathbf{1 / R 1})+\mathbf{R 2}+1)
\end{aligned}
$$

$K p=$ rate constant for abstracting a primary hydrogen $\left(H_{p}\right)$

$K_{s}=$ rate constant for abstracting a secondary hydrogen $\left(H_{S}\right)$ 
$\mathbf{K}_{\mathbf{x}}=$ rate constant for abstracting a hydrogen from the hydroxyl group $\left(H_{x}\right)$

R1 = ratio of rate constants from methanol corrected for the number of $\mathrm{H}$-atoms available for abstraction in ethanol

$\mathbf{R 2}=$ ratio of rate constants from propane corrected for the number of $\mathrm{H}$-atoms available for abstraction in ethanol

Koverall $=$ the total rate constant for the overall reaction

An example of the computed results from using this branching ratio estimation procedure is shown in figure 1 for $\mathrm{C} 2 \mathrm{H} 5 \mathrm{OH}+\mathrm{OH}=$ Products. This study used the rate coefficient measurements of Hess and Tully [17] in the 293K-750K temperature range and the shock tube results of Bott and Cohen [20] around $1200 \mathrm{~K}$ to obtain the overall rate constant to $\mathrm{C} 2 \mathrm{H} 5 \mathrm{OH}+\mathrm{OH}=$ Products. The rate constants for the $\mathrm{H}$-atom abstraction from methanol and propane by $\mathrm{OH}$ were obtained from the detailed literature review studies and theoretical analysis work of Tsang [21] and Cohen [22]. The numerical results show a branching ratio value for $\mathrm{ka} / \mathrm{kt}=$ $\mathrm{kC} 2 \mathrm{H} 5 \mathrm{OH}+\mathrm{OH}=\mathrm{CH} 3 \mathrm{CHOH}+\mathrm{H} 2 \mathrm{O} / \mathrm{koverall}$ of 0.61 at $300 \mathrm{~K}$. This value is in fair agreement to the direct product study of Meier et al. [18], who showed that $\mathrm{C} 2 \mathrm{H} 5 \mathrm{OH}+\mathrm{OH}=\mathrm{CH} 3 \mathrm{CHOH}+\mathrm{H} 2 \mathrm{O}$ accounted for $75 \pm 15 \%$ of the overall reaction at $300 \mathrm{~K}$. Around $600 \mathrm{~K}$, Hess and Tully monitored the decay rates of $18 \mathrm{OH}$ and $16 \mathrm{OH}$ radicals in the presence of ethanol $\left(\mathrm{C} 2 \mathrm{H} 5^{16} \mathrm{OH}\right)$ in order to determine the rate constant contribution from $\mathrm{C} 2 \mathrm{H} 5 \mathrm{OH}+\mathrm{OH}=\mathrm{CH} 2 \mathrm{CH} 2 \mathrm{OH}$ (or $\mathrm{C} 2 \mathrm{H} 4 \mathrm{OH})+\mathrm{H} 2 \mathrm{O}$. This product channel leads to the formation of $\mathrm{CH}_{2} \mathrm{CH}_{2}{ }^{16} \mathrm{OH}$ whereupon the $16 \mathrm{OH}$ radical is regenerated via the fast dissociation reaction $\mathrm{CH} 2 \mathrm{CH} 2^{16} \mathrm{OH}=\mathrm{C} 2 \mathrm{H} 4+{ }^{16} \mathrm{OH}$. They found the measured rate constant for the reaction of the $18 \mathrm{OH}$ radical with ethanol is ca. $18 \%$ higher than that measured for the $16 \mathrm{OH}$ reaction, and therefore the $\mathrm{C} 2 \mathrm{H} 5 \mathrm{OH}+\mathrm{OH}=\mathrm{C} 2 \mathrm{H} 4 \mathrm{OH}+\mathrm{H} 2 \mathrm{O}$ product channel accounts for approximately $15 \%-20 \%$ of the total rate constant. This study's branching ratio determination at $600 \mathrm{~K}$ suggests a value around $33 \%$ which is roughly double in value to the Hess and Tully experimental finding. Numerical modeling work on ethanol oxidation kinetics in an atmospheric flow reactor by Norton and Dryer [23] had shown branching ratios of $\mathrm{C} 2 \mathrm{H} 4 \mathrm{OH}: \mathrm{CH} 3 \mathrm{CHOH}: \mathrm{CH} 3 \mathrm{CH} 2 \mathrm{O}$ to be $30 \%: 50 \%: 20 \%$ at $1100 \mathrm{~K}$. This study's branching ratio determination for the $\mathrm{C} 2 \mathrm{H} 4 \mathrm{OH}$ product channel is in very good 
agreement with the Norton and Dryer finding at $1100 \mathrm{~K}$, however there is a fairly large discrepancy between the branching values selected for the $\mathrm{CH} 3 \mathrm{CHOH}$ and $\mathrm{CH} 3 \mathrm{CH} 2 \mathrm{O}$ product channels. This study advocates the dominance of the $\mathrm{CH} 3 \mathrm{CH} 2 \mathrm{O}$ product channel at high temperatures with branching ratio values of ca. $38 \%-48 \%$ in the $1000 \mathrm{~K}-2000 \mathrm{~K}$ temperature range, and a small relative contribution from the $\mathrm{CH} 3 \mathrm{CHOH}$ product channel of ca. $18 \%-27 \%$ in the $1000 \mathrm{~K}-2000 \mathrm{~K}$ temperature range.

This branching ratio estimation procedure was also adopted for $\mathrm{H}$ abstraction reactions involving $\mathrm{C} 2 \mathrm{H} 5 \mathrm{OH}$ and $\mathrm{O}$-atom, $\mathrm{H}$-atom, and the methyl radical. Analysis of the branching ratio values for acetaldehyde ( $\mathrm{CH} 3 \mathrm{HCO}$ ) was also performed, and will be discussed in a later paper by the author.

\section{Short Discussion on the Numerical Results}

\section{Modeling Ignition Delay in Shock Tubes}

Natarajan and Bhaskaran investigated the ignition of ethanol-oxygenargon gas mixtures behind reflected shock waves over the temperature range of $1300 \mathrm{~K}-1700 \mathrm{~K}$, at pressures of 1.0 and 2.0 atmospheres, and equivalence ratios of $0.5,1.0$ and 2.0 [24]. In the experimental investigation, the ignition event was identified by the first visible light emission, whereupon their experimental ignition delay data were found to be correlated by the global expression of $\mathrm{Tau}=10^{-15} \mathrm{Exp}(19221 \mathrm{KT})[\mathrm{C} 2 \mathrm{H} 5 \mathrm{OH}]^{0.1}[\mathrm{O} 2]^{-0.75}[\mathrm{Ar}]^{-0.25}$.

The numerical simulations of the ignition delay behind reflected shock waves were conducted using the SENKIN code assuming an adiabatic, constant volume system. This assumption allows for both the temperature and pressure to increase during the course of reaction. The theoretical ignition delay time was defined as the region where the most rapid change in temperature occurred or when the numerical computations indicated a ca. $2.0 \times 10^{-9} \mathrm{~mole} / \mathrm{cc}$ of hydroxyl $(\mathrm{OH})$ radical concentration.

In figures 2-4, the experimental data of Natarajan and Bhaskaran are presented for all conditions examined in their study, and these data are compared to the numerical computations. The numerical simulations are shown to be in excellent agreement with the full data set when considering the uncertainty associated with reflected shock wave pressure (P5). The thermal 
decomposition of ethanol has been previously suggested as the most likely initiation reaction for these conditions [25]. In the detailed chemical kinetic model, the computed ignition delay times were well reproduced when the ethanol decomposition was assumed to occur as a second order reaction.

A sensitivity analysis was conducted to assess those reactions having the greatest influence on ethanol ignition. The analysis was performed by perturbing the forward and reverse rate constants for each reaction by a factor of two thereby leaving the thermochemistry or thermodynamic equilibrium constant within the chemical reaction unaffected. The sensitivity coefficient was then determined by taking the natural logarithm of the ignition delay time calculated with the perturbed reaction kinetics divided by the baseline ignition delay value, whereupon sensitivity coefficient expression is represented as $S=\ln$ (Taupert/Tauunpert). If the sensitivity coefficient exhibits a positive value that would indicate a decrease in the overall reactivity of the chemical system, and a negative value would imply an increase in the overall reactivity of the chemical system. The sensitivity analysis study was conducted at ethanoloxygen equivalence ratios of $0.5,1.0$ and 2.0 at 1.0 atmosphere. The dominate reaction controlling ethanol ignition was $\mathrm{C} 2 \mathrm{H} 5 \mathrm{OH}+\mathrm{M}=\mathrm{CH} 2 \mathrm{OH}+\mathrm{CH} 3+\mathrm{M}$ with secondary influences on the ethanol ignition delay due to $\mathrm{H}+\mathrm{O}_{2}=\mathrm{OH}+\mathrm{O}$, $\mathrm{CH} 3+\mathrm{HO}_{2}=\mathrm{CH} 3 \mathrm{O}+\mathrm{O}, \quad \mathrm{OH}+\mathrm{HO}_{2}=\mathrm{H} 2 \mathrm{O}+\mathrm{O}_{2}, \mathrm{H}+\mathrm{HO}_{2}=\mathrm{O} 2+\mathrm{H}_{2}, \quad$ and $\mathrm{HCO}+\mathrm{M}=\mathrm{H}+\mathrm{CO}+\mathrm{M}$ and $\mathrm{HCO}+\mathrm{O} 2=\mathrm{CO}+\mathrm{HO} 2$ at only lean conditions. The $\mathrm{H}$-atom abstraction reactions from ethanol do not play an important role in ignition delay according to the numerical simulations of this study. Sensitivity and rate flux analysis indicate that the decomposition of ethanol under shock tube conditions primarily proceeds by the following reaction steps

$\mathrm{C} 2 \mathrm{H} 5 \mathrm{OH}+\mathrm{M}=\mathrm{CH} 3+\mathrm{CH} 2 \mathrm{OH}+\mathrm{M}$
$\mathrm{CH} 2 \mathrm{OH}+\mathrm{O} 2=\mathrm{CH} 2 \mathrm{O}+\mathrm{HO} 2$
$\mathrm{CH} 3+\mathrm{HO} 2=\mathrm{CH} 3 \mathrm{O}+\mathrm{OH}$
$\mathrm{CH} 3 \mathrm{O}+\mathrm{M}=\mathrm{CH} 2 \mathrm{O}+\mathrm{H}+\mathrm{M}$
$\mathrm{CH} 2 \mathrm{O}+\mathrm{X}=\mathrm{HCO}+\mathrm{XH} \quad(\mathrm{X}=\mathrm{OH}, \mathrm{H})$
$\mathrm{HCO}+\mathrm{M}=\mathrm{H}+\mathrm{CO}+\mathrm{M}$
$\mathrm{HCO}+\mathrm{O} 2=\mathrm{CO}+\mathrm{HO} 2$
$\mathrm{CO}+\mathrm{OH}=\mathrm{CO} 2+\mathrm{H}$


Modeling Laminar Burning Velocities in Freely Propagating Flames

Gulder investigated laminar burning velocities or flame speeds $\left(\mathrm{S}_{\mathrm{U}}\right)$ of ethanol-air gas mixtures in a constant volume bomb for a wide range of unburned gas pressures $(\mathrm{Pu}), 0.1-0.8 \mathrm{MPa}$, unburned gas temperatures $\left(T_{u}\right)$, 300K-500K, and equivalence ratios, 0.7-1.4 [26]. The maximum uncertainty determined for the measured laminar flame speeds was $\pm 2.0 \mathrm{~cm} / \mathrm{sec}$ based on the uncertainities associated in the measured unburned gas mixture temperature $( \pm 3.0 \mathrm{~K})$, unburned gas mixture pressure $( \pm 1 \%)$, and equivalence ratio $( \pm 0.015)$. The experimental data showed the maximum laminar flame speed for ethanol occurred around an equivalence ratio of 1.075 with a value of $47 \mathrm{~cm} / \mathrm{sec}$ at $0.1 \mathrm{MPa}$. At elevated pressures, the ethanol-air laminar speeds decreased with pressure while exhibited the following pressure dependences with equivalence ratio, $S_{u}=S_{u}$, ref $(P)^{-0.17} \sqrt{\phi}$ for $\phi \geq 1.0$, and

$S_{u}=S_{u, \operatorname{ref}}(P)^{-0.17 / \sqrt{\phi}}$ for $\phi \leq 1.0$, where $300 \mathrm{~K}$ and $0.1 \mathrm{MPa}$ are the reference conditions.

The numerical simulations of the laminar flame speeds were conducted using the PREMIX code. The numerical computations performed in this study were only carried out at unburned gas pressures of $0.1 \mathrm{MPa}$ and $0.2 \mathrm{MPa}$ for the full equivalence ratio range studied at $300 \mathrm{~K}$. On going work is being performed to analyze the chemical behavior of ethanol in air at elevated pressures, and the results along with the predicted flame speeds will be presented at a later date.

Figures 6 and 7 show the numerically calculated results and their relatively close agreement with the experimental data. The extrapolated laminar flame speed data of Egolfopoulos et al. [27] from flame speed measurements periormed at higher unburned gas temperatures, 363K-453K, are also shown for comparison. The numerical results tend to reflect a slight flame speed overprediction by ca. $3.0 \mathrm{~cm} / \mathrm{sec}$ in the $0.7-0.8$ equivalence ratio range, and underprediction by ca. $2.0 \mathrm{~cm} / \mathrm{sec}$ in the $1.05-1.15$ equivalence ratio range. Otherwise, good agreement with the experimental data is shown at the other equivalence ratios. Lastly, the model is able to predict correctly the location of the maximum flame speed for unburned gas pressures of $0.1 \mathrm{MPa}$ and $0.2 \mathrm{MPa}$.

Sensitivity analysis was performed to determine the influence of those chemical reactions and their associated kinetic rates on the mass burning rate, 
$M=p_{u} S_{u}$, where $p_{u}$ refers to the density of the unburned gas mixture. The normalized sensitivity coefficients were calculated using the expression, $\left(A_{i} / M\right)\left(\Delta M / \Delta A_{i}\right)$, where $A_{i}$ is the pre-exponential factor of the $i$ th kinetic rate constant. The results of the sensitivity analysis are presented in figure 8 . At $\phi=0.6$, the $\mathrm{CO}+\mathrm{OH}=\mathrm{CO} 2+\mathrm{H}$ reaction is the most sensitive reaction found in lean ethanol-air freely propagating laminar flames, followed by $\mathrm{H}+\mathrm{O} 2=\mathrm{OH}+\mathrm{O}$, $\mathrm{HCO}+\mathrm{O} 2=\mathrm{CO}+\mathrm{HO} 2, \quad \mathrm{HCO}+\mathrm{M}=\mathrm{H}+\mathrm{CO}+\mathrm{M}, \mathrm{H}+\mathrm{O} 2+\mathrm{N2}=\mathrm{HO} 2+\mathrm{N} 2$, and $\mathrm{CH} 2 \mathrm{HCO}=\mathrm{CH} 2 \mathrm{CO}+\mathrm{H}$. As the equivalence ratios progressively become richer, the $\mathrm{H}+\mathrm{O} 2=\mathrm{OH}+\mathrm{O}$ reaction exhibits the greatest sensitivity, while the $\mathrm{CO}+\mathrm{OH}=\mathrm{CO} 2+\mathrm{H}$ reaction dramatically decreases in sensitivity. This is due to the limited production of $\mathrm{H}$-atoms from $\mathrm{CO}$ conversion to $\mathrm{CO} 2$ by $\mathrm{OH}$ at rich conditions as other reaction intermediates are able to compete more effectively for $\mathrm{OH}$.

These sensitivity analysis results indicate the importance of $\mathrm{H}$-atom sources and sinks when modeling ethanol-air laminar flame speeds. Reactions such as $\mathrm{CO}+\mathrm{OH}=\mathrm{CO} 2+\mathrm{H}, \mathrm{HCO}+\mathrm{M}=\mathrm{H}+\mathrm{CO}+\mathrm{M}, \mathrm{CH} 2 \mathrm{HCO}=\mathrm{CH} 2 \mathrm{CO}+\mathrm{H}$ exhibit positive sensitivity coefficents thereby enhancing the flame speed or the overall reactivity of the chemical system since they are the primary producers of $\mathrm{H}$ atoms. The $\mathrm{H}+\mathrm{O}_{2}=\mathrm{OH}+\mathrm{O}$ and $\mathrm{H}+\mathrm{HO} 2=\mathrm{OH}+\mathrm{OH}$ reactions, although consumers of $\mathrm{H}$-atoms, also exhibit a positive sensitivity coefficients as they produce reactive $\mathrm{OH}$ and $\mathrm{O}$ radicals that are necessary to consume ethanol and its reaction intermediates. The $\mathrm{H}+\mathrm{O} 2+\mathrm{N} 2=\mathrm{HO}_{2}+\mathrm{N} 2$ and $\mathrm{HCO}+\mathrm{O}_{2}=\mathrm{CO}+\mathrm{HO}_{2}$ reactions retard flame speeds by limiting the amount of net $\mathrm{H}$-atom produced, and instead allow the formation of the unreactive hydroperoxyl (HO2) radical. The ethanol decomposition reaction, $\mathrm{C} 2 \mathrm{H} 5 \mathrm{OH}+\mathrm{M}=\mathrm{CH} 3+\mathrm{CH} 2 \mathrm{OH}+\mathrm{M}$, was determined to be relatively unimportant in modeling laminar flame speeds although a small positive sensitivity coefficient is exhibited at fuel-rich conditions.

\section{Modeling Species Concentrations from a Flow Reactor}

Norton and Dryer performed an experimental and modeling study of ethanol oxidation kinetics in a turbulent flow reactor [23]. They reported experimental profiles of the stable species concentrations and temperatures for ethanol oxidation at atmospheric pressure, initial temperatures near $1100 \mathrm{~K}$, and 
equivalence ratios. of $0.61-1.24$. They found acetaldehyde, ethylene and methane in nearly equal concentrations and as the major reaction intermediates produced for the experimental conditions examined. Their chemical kinetic modeling results showed very good agreement with the experimental data, and they noted the importance of selecting the proper branching ratios for reactions involving ethanol with $\mathrm{OH}$ and $\mathrm{H}$-atom.

The experimental data of Norton and Dryer were used to validate the current chemical kinetic model by comparing the predicted stable species profiles to those measured during the ethanol oxidation process. The numerical computations were performed for only the $\phi=0.61$ case, and the results are shown in figures 9,10 and 11 . The presentation and analysis of the remaining experimental data sets, $\phi=0.81$, and $\phi=1.24$ will reported at a later date.

In figure 9, a comparison of the experimental data against the numerically computed species concentrations on a mole percent basis is shown for $\mathrm{C} 2 \mathrm{H} 5 \mathrm{OH}, \mathrm{O} 2, \mathrm{CO}, \mathrm{CO} 2, \mathrm{H} 2$, and $\mathrm{H} 2 \mathrm{O}$. Due to the uncertainty in the experimental induction time, the numerical results had to be "time shifted" [23] in order to match the experimental data at the $50 \%$ fuel decay point. The amount of the shift was approximately $15 \mathrm{msec}$. The results show relatively good agreement except at the first data point. The differences in the initial slope of the ethanol profile maybe due to the reported uncertainty in the measured temperature profile which was estimated to be $\pm 10 \mathrm{~K}$. The $\mathrm{O} 2, \mathrm{H} 2, \mathrm{H} 2 \mathrm{O}$, and $\mathrm{CO} 2$ species were shown to be fairly well predicted although modeling discrepancies exist for the proper prediction of the $\mathrm{CO}$ profile. The calculated profiles for the reaction intermediates, $\mathrm{CH} 4, \mathrm{C} 2 \mathrm{H} 2, \mathrm{C} 2 \mathrm{H} 4, \mathrm{C} 2 \mathrm{H} 6, \mathrm{CH} 3 \mathrm{HCO}$, and $\mathrm{C} 3 \mathrm{H} 6$ are shown in figures 10 and 11 . The numerical results show a good representation of the $\mathrm{CH} 3 \mathrm{HCO}, \mathrm{C} 2 \mathrm{H} 4$, and $\mathrm{C} 2 \mathrm{H} 2$ profiles although $\mathrm{CH}_{4}, \mathrm{C} 2 \mathrm{H} 6$, and $\mathrm{C} 3 \mathrm{H} 6$ are slightly underpredicted. The underprediction of the $\mathrm{CH} 4, \mathrm{C} 2 \mathrm{H} 6$, and $\mathrm{C} 3 \mathrm{H} 6$ profiles could be most likely due to either the overoxidation of the methyl radical or that simply not enough methyl radical was being produced in the chemical kinetic model.

Reaction flux analysis was performed to determine the production routes for the many reaction intermediates formed. Acetaldehyde ( $\mathrm{CH} 3 \mathrm{HCO}$ ) was primarily formed through the reaction sequence of $\mathrm{C} 2 \mathrm{H} 5 \mathrm{OH}+\mathrm{OH}=\mathrm{CH} 3 \mathrm{CHOH}+\mathrm{H} 2 \mathrm{O}$ followed by $\mathrm{CH} 3 \mathrm{CHOH}+\mathrm{O} 2=\mathrm{CH} 3 \mathrm{HCO}+\mathrm{HO} 2$ and secondarily by $\mathrm{C} 2 \mathrm{H} 5 \mathrm{OH}+\mathrm{OH}=\mathrm{CH} 3 \mathrm{CH} 2 \mathrm{O}+\mathrm{H} 2 \mathrm{O}$ and $\mathrm{CH} 3 \mathrm{CH} 2 \mathrm{O}+\mathrm{M}=$ $\mathrm{CH} 3 \mathrm{HCO}+\mathrm{H}+\mathrm{M}$. Methane formation is primarily controlled by $\mathrm{C} 2 \mathrm{H} 5 \mathrm{OH}+\mathrm{CH} 3=$ 
$\mathrm{CH} 3 \mathrm{CHOH}+\mathrm{CH} 4$ and $\mathrm{CH} 3+\mathrm{HO} 2=\mathrm{CH} 4+\mathrm{O} 2$. Ethane was formed exclusively by $\mathrm{CH} 3+\mathrm{CH} 3(+\mathrm{M})=\mathrm{C} 2 \mathrm{H} 6(+\mathrm{M})$. Ethylene was formed principally by the reaction sequence of $\mathrm{C} 2 \mathrm{H} 5 \mathrm{OH}+\mathrm{OH}=\mathrm{C} 2 \mathrm{H} 4 \mathrm{OH}+\mathrm{H} 2 \mathrm{O}$, and $\mathrm{C} 2 \mathrm{H} 4 \mathrm{OH}=\mathrm{C} 2 \mathrm{H} 4+\mathrm{OH}$. Acetylene was formed via ethylene through the reactions sequence of $\mathrm{C} 2 \mathrm{H} 4+\mathrm{OH}=\mathrm{C} 2 \mathrm{H} 3+\mathrm{H} 2 \mathrm{O}$, and $\mathrm{C} 2 \mathrm{H} 3+\mathrm{O} 2$ metathesis to $\mathrm{C} 2 \mathrm{H} 2+\mathrm{HO} 2$. Lastly, propene $(\mathrm{C} 3 \mathrm{H} 6)$ was formed by vinyl $(\mathrm{C} 2 \mathrm{H} 3)$ and methyl $(\mathrm{CH} 3)$ radical combination.

A sensitivity analysis study was conducted for the purposes of determining the most important reactions which strongly influence the overall rate of ethanol oxidation at lean conditions. The analysis was performed by perturbing the forward and reverse rate constants for each reaction by a factor of two thereby leaving the thermochemistry or thermodynamic equilibrium constant within the chemical reaction unaffected. The sensitivity coefficient was then determined by taking the natural logarithm of the mole fraction of ethanol remaining after $20 \mathrm{msec}$. of computed oxidation time with the perturbed reaction kinetics divided by the baseline mole fraction of ethanol remaining after 20 msec. The sensitivity coefficient is expressed as $S=\ln \left(X_{C 2} h 50 h\right.$,pert $\left./ X_{C 2 h 5 o h, u n p e r t}\right)$. If the sensitivity coefficient exhibits a positive value that would indicate a decrease in the overall reactivity of the chemical system, and a negative value would imply an increase in the overall reactivity of the chemical system. Figure 12 shows the results of the sensitivity analysis performed for the $\phi=0.61$ case. The $\mathrm{H}+\mathrm{O} 2=\mathrm{OH}+\mathrm{O}$ reaction is shown to be the most sensitive reaction to the overall rate of ethanol oxidation at lean conditions, followed by $\mathrm{CH} 3+\mathrm{HO}_{2}$ reaction to $\mathrm{CH} 3 \mathrm{O}+\mathrm{OH}$ and $\mathrm{CH} 4+\mathrm{O} 2$ products, $\mathrm{CH} 3 \mathrm{CH} 2 \mathrm{O}$ decomposition to $\mathrm{CH} 3+\mathrm{CH} 2 \mathrm{O}$ and $\mathrm{CH} 3 \mathrm{HCO}+\mathrm{H}$, ethanol decomposition, and the $\mathrm{H}$-atom abstraction reaction by $\mathrm{OH}$ and $\mathrm{HO} 2$ of ethanol. The $\mathrm{H}+\mathrm{O} 2$ chain branching reaction exhibits a large negative sensitivity coefficient largely due to the early production of $\mathrm{H}$-atom that evolves from the reaction sequence of $\mathrm{C} 2 \mathrm{H} 5 \mathrm{OH}+\mathrm{OH}=\mathrm{CH} 3 \mathrm{CH} 2 \mathrm{O}+\mathrm{H} 2 \mathrm{O}$ followed by $\mathrm{CH} 3 \mathrm{CH} 2 \mathrm{O}+\mathrm{M}=\mathrm{CH} 3 \mathrm{HCO}+\mathrm{H}+\mathrm{M}$. The $\mathrm{CH} 3 \mathrm{CH} 2 \mathrm{O}$ decomposition exhibits both a large positive and negative sensitivity coefficient as shown in figure 12. The branching ratio for $\mathrm{CH} 3 \mathrm{CH} 2 \mathrm{O}$ decomposition to $\mathrm{CH} 3 \mathrm{HCO}+\mathrm{H}$ and $\mathrm{CH} 3+\mathrm{CH} 2 \mathrm{O}$ products was largely determined by matching the $\mathrm{CH} 3 \mathrm{HCO}, \mathrm{CH} 4$ and $\mathrm{C} 2 \mathrm{H} 5 \mathrm{OH}$ profiles in the present analysis. The rate constant assigned to each reaction was verified by performing a QRRK analysis on the $\mathrm{CH} 3+\mathrm{CH} 2 \mathrm{O} \leftrightarrow \mathrm{CH} 3 \mathrm{CH} 2 \mathrm{O} \leftrightarrow \mathrm{CH} 3 \mathrm{HCO}+\mathrm{H}$ reaction network. The rate constant 
choices were within a factor of two agreement with the QRRK study. Interestingly, reaction flux analysis indicates the $\mathrm{C} 2 \mathrm{H} 5 \mathrm{OH}+\mathrm{OH}=\mathrm{CH} 3 \mathrm{CH} 2 \mathrm{O}+\mathrm{H} 2 \mathrm{O}$ reaction is one of the dominant ethanol consuming reactions yet this reaction does not appear to be very sensitive or important to the overall ethanol oxidation rate according to figure 12 . This finding is a little misleading in that the sensitivity exhibited by $\mathrm{C} 2 \mathrm{H} 5 \mathrm{OH}+\mathrm{OH}=$ Products is largely due to the radical it produces. In the case of $\mathrm{C} 2 \mathrm{H} 5 \mathrm{OH}+\mathrm{OH}=\mathrm{CH} 3 \mathrm{CH} 2 \mathrm{O}+\mathrm{H} 2 \mathrm{O}$, the $\mathrm{CH} 3 \mathrm{CH} 2 \mathrm{O}$ radical decomposes to either $\mathrm{CH} 3 \mathrm{HCO}+\mathrm{H}$ or $\mathrm{CH} 3+\mathrm{CH} 2 \mathrm{O}$ were each pathway negates the other on their respective affect on the overall ethanol oxidation rate. This would explain way the $\mathrm{C} 2 \mathrm{H} 5 \mathrm{OH}+\mathrm{OH}=\mathrm{CH} 3 \mathrm{CH} 2 \mathrm{O}+\mathrm{H} 2 \mathrm{O}$ reaction does not appear to be sensitive. It must be emphasized that the branching ratios selected for $\mathrm{C} 2 \mathrm{H} 5 \mathrm{OH}+\mathrm{OH}=$ Products are very important in determining the correct product profiles found in the ethanol oxidation flow reactor studies as well as obtaining the correct overall reactivity exhibited within the chemical system. The $\mathrm{C} 2 \mathrm{H} 5 \mathrm{OH}+\mathrm{OH}=\mathrm{C} 2 \mathrm{H} 4 \mathrm{OH}+\mathrm{H} 2 \mathrm{O}$ reaction exhibits a positive sensitivity coefficient as the $\mathrm{C} 2 \mathrm{H} 4 \mathrm{OH}$ radical subsequently decomposes to $\mathrm{C} 2 \mathrm{H} 4$ and $\mathrm{OH}$. The regeneration of the $\mathrm{OH}$ radical permits an additional amount of ethanol to be consumed by $\mathrm{OH}$ attack. The sensitivity analysis results also show the important influence the $\mathrm{HO} 2$ radical has on the overall ethanol oxidation rate. Chain terminating reactions like $\mathrm{CH} 3+\mathrm{HO} 2=\mathrm{CH} 4+\mathrm{O} 2$ and $\mathrm{H}+\mathrm{HO} 2=\mathrm{H} 2+\mathrm{O} 2$ tend to retard the ethanol oxidation process while chain branching or propagating reactions like $\mathrm{CH} 3+\mathrm{HO} 2=\mathrm{CH} 3 \mathrm{O}+\mathrm{OH}$ (followed by $\mathrm{CH} 3 \mathrm{O}+\mathrm{M}=\mathrm{CH} 2 \mathrm{O}+\mathrm{H}+\mathrm{M}$ ) and $\mathrm{H}+\mathrm{HO} 2=\mathrm{OH}+\mathrm{OH}$ tend to increase the rate of ethanol oxidation. Finally, the $\mathrm{C} 2 \mathrm{H} 5 \mathrm{OH}+\mathrm{HO} 2=\mathrm{CH} 3 \mathrm{CHOH}+\mathrm{H} 2 \mathrm{O} 2$ reaction was shown to exhibit a negative sensitivity coefficient at lean conditions due to the chain branching that occurs through $\mathrm{H} 2 \mathrm{O} 2$ decomposition. This is explained by the reaction sequence of $\mathrm{C} 2 \mathrm{H} 5 \mathrm{OH}+\mathrm{HO} 2=\mathrm{CH} 3 \mathrm{CHOH}+\mathrm{H} 2 \mathrm{O} 2, \mathrm{CH} 3 \mathrm{CHOH}+\mathrm{O} 2=\mathrm{CH} 3 \mathrm{HCO}+\mathrm{HO} 2$, followed by $\mathrm{H} 2 \mathrm{O} 2+\mathrm{M}=\mathrm{OH}+\mathrm{OH}+\mathrm{M}$.

\section{Summary}

A chemical kinetic modeling investigation was presented which successfully reproduced the measurements from three different experimental systems. The modeling study of ignition delay in shock tubes noted the 
importance of the $\mathrm{C} 2 \mathrm{H} 5 \mathrm{OH}+\mathrm{M}=\mathrm{CH} 3+\mathrm{CH} 2 \mathrm{OH}+\mathrm{M}$ reaction. Ignition delay times were successfully reproduce when representing ethanol decomposition as a second order reaction. The modeling study of laminar burning velocities in freely propagating flames showed that proper characterization of the $\mathrm{H}$-atom production and consumption steps and associated kinetics are very important for proper prediction of laminar flames speeds in ethanol-air mixtures. Flow reactor modeling of ethanol oxidation at lean conditions showed large sensitivity coefficients are found for the $\mathrm{H}+\mathrm{O} 2$ chain branching reaction, $\mathrm{C} 2 \mathrm{H} 5 \mathrm{OH}+\mathrm{OH}, \mathrm{CH} 3 \mathrm{CH} 2 \mathrm{O}$ decomposition to $\mathrm{CH} 3+\mathrm{CH} 2 \mathrm{O}$ and $\mathrm{CH} 3 \mathrm{HCO}+\mathrm{H}$ products, and $\mathrm{HO} 2$ reactions with ethanol, $\mathrm{H}$-atoms and $\mathrm{CH} 3$ radicals.

\section{Acknowledgements}

The author is very pleased to acknowledge the helpful assistance of Lila Chase on the numerical modeling simulations, and Henry Curran on discussions concerning shock tubes.

\footnotetext{
Work performed under the auspices of the U.S. Department of Energy by Lawrence Livermore National Laboratory under contract number W-7405-ENG-48.
}

\section{References}

1. Kee, R.J., Rupley, F.M., and Miller, J.A., "CHEMKIN-II: A Fortran Chemical Kinetics Package for the Analysis of Gas Phase Chemical Kinetics", Sandia Report \#SAND 89-8009, Sandia National Laboratories, 1989.

2. Lutz, A.E., Kee, R.J., and Miller, J.A., "SENKIN: A Fortran Program for Predicting Homogeneous Gas Phase Chemical Kinetics with Sensitivity Analysis", Sandia Report \#SAND87-8248, Sandia National Laboratories, 1987.

3. Kee, R.J., Grcar, J.F., Smooke, M.D., and Miller, J.A., "A Fortran Program for Modelling Steady One-Dimensional Premixed Flames", Sandia Report \#SAND85-8240, Sandia National Laboratories, 1985.

4. Kee, R.J., Rupley, F.M., and Miller, J.A., "The Chemkin Thermodynamic Database", Sandia Report \#SAND87-8215B, Sandia National Laboratories, 1987. 
5. Burcat, A., and McBride, B., "1994 Ideal Gas Thermodynamic Data for Combustion and Air-Pollution Use", Technion Report \#TAE 697, 1993.

6. Benson, S.W., Thermochemical Kinetics, Second Edition, John Wiley and Sons, New York, 1976.

7. Cohen, N. and Benson, S.W., Chem. Rev., 93, p.2419 (1993).

8. Ritter, E.R., and Bozzelli, J.W., Int. J. Chem. Kinet., 23, pp.767-778 (1991).

9. Gordon, S., and McBride, B.J., "Computer Program for Calculation of Complex Chemical equilibrium Compositions, Rocket Performance, Incident and Reflected Shocks and Chapman-Jouget Detonations", NASA SP-273, 1971.

10. Kee, R.J., Dixon-Lewis, G., Warnatz, J., Coltrin, M.E., and Miller, J.A., "The Chemkin Transport Database", Sandia Report \#SAND86-8246, Sandia National Laboratories, 1986.

11. Wang, H., and Frenklach, M., Combust. Flame, 96, p.163 (1994).

12. Marinov, N.M., Westbrook, C.K., and Pitz, W.J., Transport Phenomena in Combustion, Ed. S.H. Chen, Eighth International Symposium on Transport Processes, p. 118, 1996.

13. Marinov, N.M., Pitz, W.J., Westbrook, C.K., Castaldi, M.J., and Senkan, S.M.,Comb. Sci. and Tech., 116-117, pp. 211-287, (1996).

14. Castaldi, M.J., Marinov, N.M., Melius, C.F., Huang, J., Senkan, S.M., Pitz, W.J., and Westbrook, C.K., Twenty-Sixth Symposium (International) on Combustion, In press, The Combustion Institute, (1996).

15. Marinov, N.M., and Malte, P.C., Int. J. Chem. Kinet., 27, p.957, (1995). 
16. Marinov, N.M., Pitz, W.J., Westbrook, C.K., Vincitore, A.M., Castaldi, M.J., Senkan, S.M., and Melius, C.F., Submitted to Comb. Flame, (1997).

17. Hess, W.P., and Tully, F.P., Chem. Phys. Lett., 152, pp.183-189, (1989).

18. Meier, U., Grotheer, H.H., Riekert, G., and Just, Th., Ber. Bunsenges. Physik. Chem., 89, p.325, (1985).

19. Gray, P. and Herod, A.A., Trans. Faraday Soc., 64, pp.1568-1576, (1968).

20. Bott, J.F., and Cohen, N., Int. J. Chem. Kinet., 23, pp.1075-1094, (1991).

21. Tsang, W., J. Phys. Chem. Ref. Data, 16, p.471, (1987).

22. Cohen, N., Int. J. Chem. Kinet., 23, pp.683-691, (1991).

23. Norton, T.S., and Dryer, F.L., Int. J. Chem. Kinet., 24, pp.319-344, (1992).

24. Natarajan, K., and Bhaskaran, K.A., Thirteenth International Shock Tube Symposium, Niagara Falla, p. 834, 1981.

25. Cooke, D.F., Dodson, M.G., and Williams, A., Combust. Flame, 16, p.233, (1971).

26. Gulder, O.L., Nineteenth Symposium (International) on Combustion, p. 275, The Combustion Institute, 1982.

27. Egolfopolous, F.N., Du, D.X., and Law, C.K., Twenty-Fourth Symposium (International) on Combustion, p. 833, The Combustion Institute, 1992. 


\section{Figure Captions:}

Figure 1: The $\mathrm{C} 2 \mathrm{H} 5 \mathrm{OH}+\mathrm{OH}=$ Products branching ratio values as calculated per text discussion calculated for the 300K-2000K temperature range. $\mathrm{kt}$ is the overall reaction rate for $\mathrm{C} 2 \mathrm{H} 5 \mathrm{OH}+\mathrm{OH}=\mathrm{Products}, \mathrm{ka}$ is the rate constant assigned to $\mathrm{C} 2 \mathrm{H} 5 \mathrm{OH}+\mathrm{OH}=\mathrm{CH} 3 \mathrm{CHOH}+\mathrm{H} 2 \mathrm{O}$, $\mathrm{Kb}$ is the rate constant assigned to $\mathrm{C} 2 \mathrm{H} 5 \mathrm{OH}+\mathrm{OH}=\mathrm{C} 2 \mathrm{H} 4 \mathrm{OH}+\mathrm{H} 2 \mathrm{O}$, and $\mathrm{k}_{\mathrm{C}}$ is the rate constant assigned to $\mathrm{C} 2 \mathrm{H} 5 \mathrm{OH}+\mathrm{OH}=\mathrm{CH} 3 \mathrm{CH} 2 \mathrm{O}+$ $\mathrm{H} 2 \mathrm{O}$. Solid symbols refer to experimental data, open symbols refer to chemical kinetic modeling determination of the branching ratios.

Figure 2: Comparison between experimental (symbols) shock tube ignition delay data as investigated by Natarjan and Bhaskaran [24] and the numerical calculations (lines) using the chemical kinetic model. Experimental conditions: $1.43 \% \mathrm{C} 2 \mathrm{H} 5 \mathrm{OH}, 8.57 \% \mathrm{O} 2$, and $90 \%$ Ar $\mathrm{C} 2 \mathrm{H} 5 \mathrm{OH}+\mathrm{OH}=\mathrm{CH} 3 \mathrm{CH} 2 \mathrm{O}+\mathrm{H} 2 \mathrm{O}$. (equivalence ratio=0.5), and $1.0 \pm 0.2$ and $2.0 \pm 0.2$ atmospheres.

Figure 3: Comparison between experimental (symbols) shock tube ignition delay data as investigated by Natarjan and Bhaskaran [24] and the numerical calculations (lines) using the chemical kinetic model. Experimental conditions: $2.5 \% \mathrm{C} 2 \mathrm{H} 5 \mathrm{OH}, 7.5 \% \mathrm{O} 2$, and $90 \%$ Ar (equivalence ratio=1.0), and 1.0 \pm 0.2 and 2.0 $10.2 \mathrm{~atm}$.

Figure 4: Comparison between experimental (symbols) shock tube ignition delay data as investigated by Natarjan and Bhaskaran [24] and the numerical calculations (lines) using the chemical kinetic model. Experimental conditions: $4.0 \% \mathrm{C} 2 \mathrm{H} 5 \mathrm{OH}, 6.0 \% \mathrm{O} 2$, and

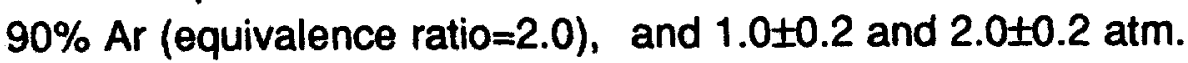

Figure 5: First order sensitivity coefficients of the most important reactions on the ignition delay time of lean, stoichiometric, and rich ethanol gas mixtures. Pressure=1.0 atmosphere.

Figure 6: Comparison between experimental (symbols) laminar flame speeds as a function of equivalence ratio as investigated by Gulder [26] and the numerical calculations (lines) using the detailed chemical kinetic model. The extrapolated data of Egolfopoulos et al. [27] is also shown for comparison.

Model calculations were performed at $P_{U}=0.1 \mathrm{MPa}$ and $T_{U}=300 \mathrm{~K}$.

Figure 7: Comparison between experimental (symbols) laminar flame speeds as a function of equivalence ratio as investigated by Gulder [26] and the numerical calculations (lines) using the detailed chemical kinetic model. Experimental conditions were $P_{u}=0.2 \mathrm{MPa}$ and $T_{u}=300 \mathrm{~K}$. 
Figure 8: Normalized first order sensitivity coefficients of the most important reactions on the mass burning rate of lean, stoichiometric and rich ethanol/air flames at $\mathrm{Pu}_{u}=0.1 \mathrm{MPa}$ and $\mathrm{T}_{u}=300 \mathrm{~K}$.

Figure 9: Comparison between experimental (symbols) flow reactor oxidation data for $\phi=0.61$ as investigated by Norton and Dryer [23] and the numerical calculations (lines) using the detailed chemical kinetic model. The numerical results were time "shifted" by ca. -15 msec. Experimental conditions: $5.65 \% \mathrm{C} 2 \mathrm{H} 5 \mathrm{OH}$, $2.786 \%$ O2, and $96.649 \%$ Nitrogen, Reynolds Number $=7140$, $\mathrm{P}=1 \mathrm{~atm}$., and $\mathrm{T}$ in $=1092 \mathrm{~K}$. Numerical simulations shown for $\mathrm{C} 2 \mathrm{H} 5 \mathrm{OH}, \mathrm{O} 2, \mathrm{CO}, \mathrm{CO} 2, \mathrm{H} 2$, and $\mathrm{H} 2 \mathrm{O}$.

Figure 10: Comparison between experimental (symbols) flow reactor oxidation data for $\phi=0.61$ as investigated by Norton and Dryer [23] and the numerical calculations (lines) using the detailed chemical kinetic model. The numerical results were time "shifted" by ca. $-15 \mathrm{msec}$. Experimental conditions: $5.65 \% \mathrm{C} 2 \mathrm{H} 5 \mathrm{OH}$, $2.786 \%$ O2, and $96.649 \%$ Nitrogen, Reynolds Number $=7140$, $\mathrm{P}=1 \mathrm{~atm}$., and $\mathrm{Tin}=1092 \mathrm{~K}$. Numerical simulations shown for $\mathrm{CH} 3 \mathrm{HCO}, \mathrm{C}_{2} \mathrm{H} 4, \mathrm{CH} 4, \mathrm{C} 2 \mathrm{H} 6$, and $\mathrm{C} 2 \mathrm{H} 2$.

Figure 11: Comparison between experimental (symbols) flow reactor oxidation data for $\phi=0.61$ as investigated by Norton and Dryer [23] and the numerical calculations (lines) using the detailed chemical kinetic model. The numerical results were time "shifted" by ca. -15 msec. Experimental conditions: $5.65 \% \mathrm{C} 2 \mathrm{H} 5 \mathrm{OH}$, $2.786 \%$ O2, and $96.649 \%$ Nitrogen, Reynolds Number $=7140$, $\mathrm{P}=1 \mathrm{~atm}$., and $\mathrm{T}_{\text {in }}=1092 \mathrm{~K}$. Numerical simulation shown for $\mathrm{C} 3 \mathrm{H} 6$ (propene).

Figure 12: First order sensitivity coefficients of the most important reactions affecting the ethanol consumption rate. See text for discussion. Experimental conditions: $5.65 \% \mathrm{C} 2 \mathrm{H} 5 \mathrm{OH}, 2.786 \% \mathrm{O} 2$, and $96.649 \%$ Nitrogen, Reynolds Number $=7140, P=1$ atm., and $\mathrm{T}_{\text {in }}=1092 \mathrm{~K}$. 


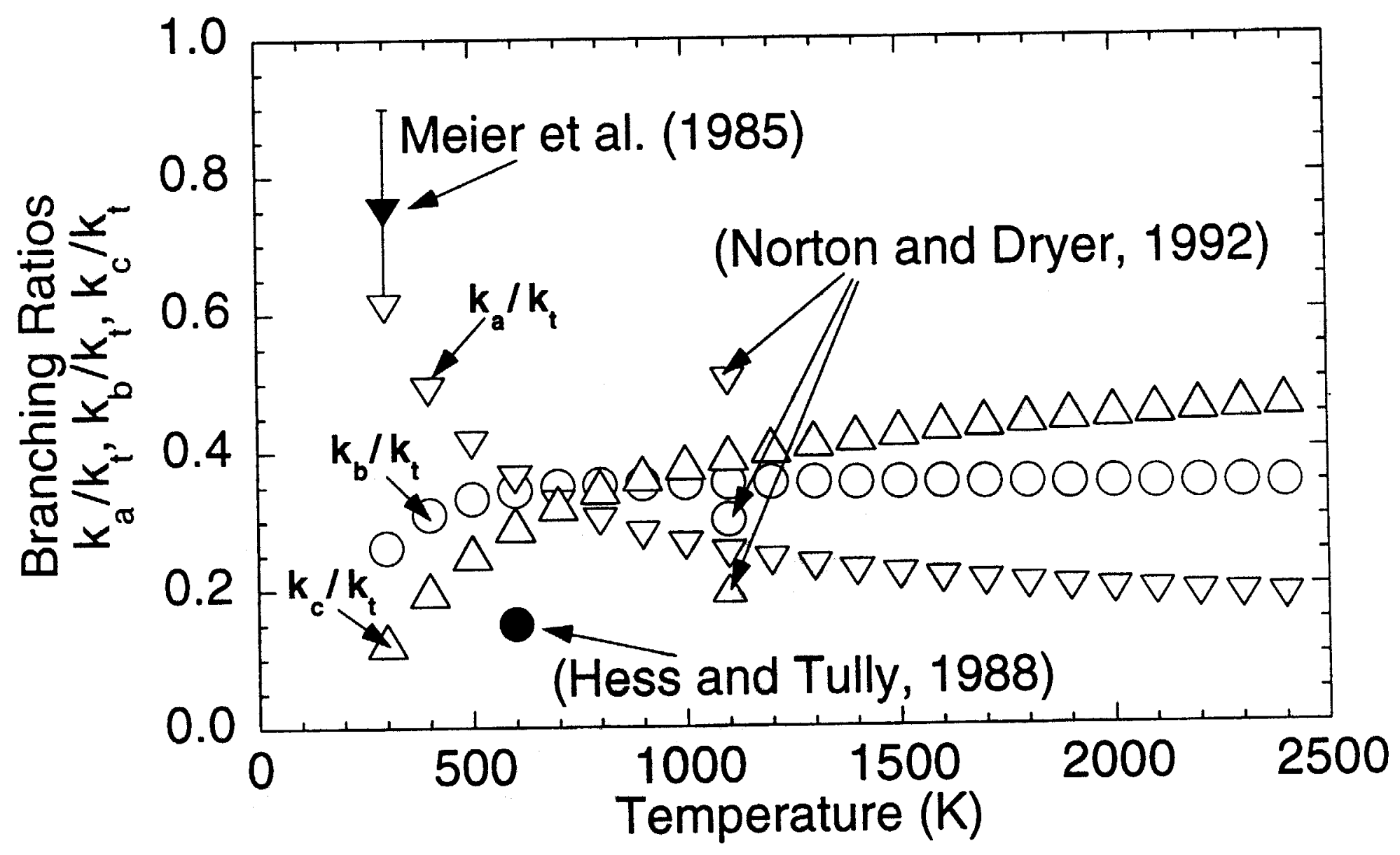

Fig.l 


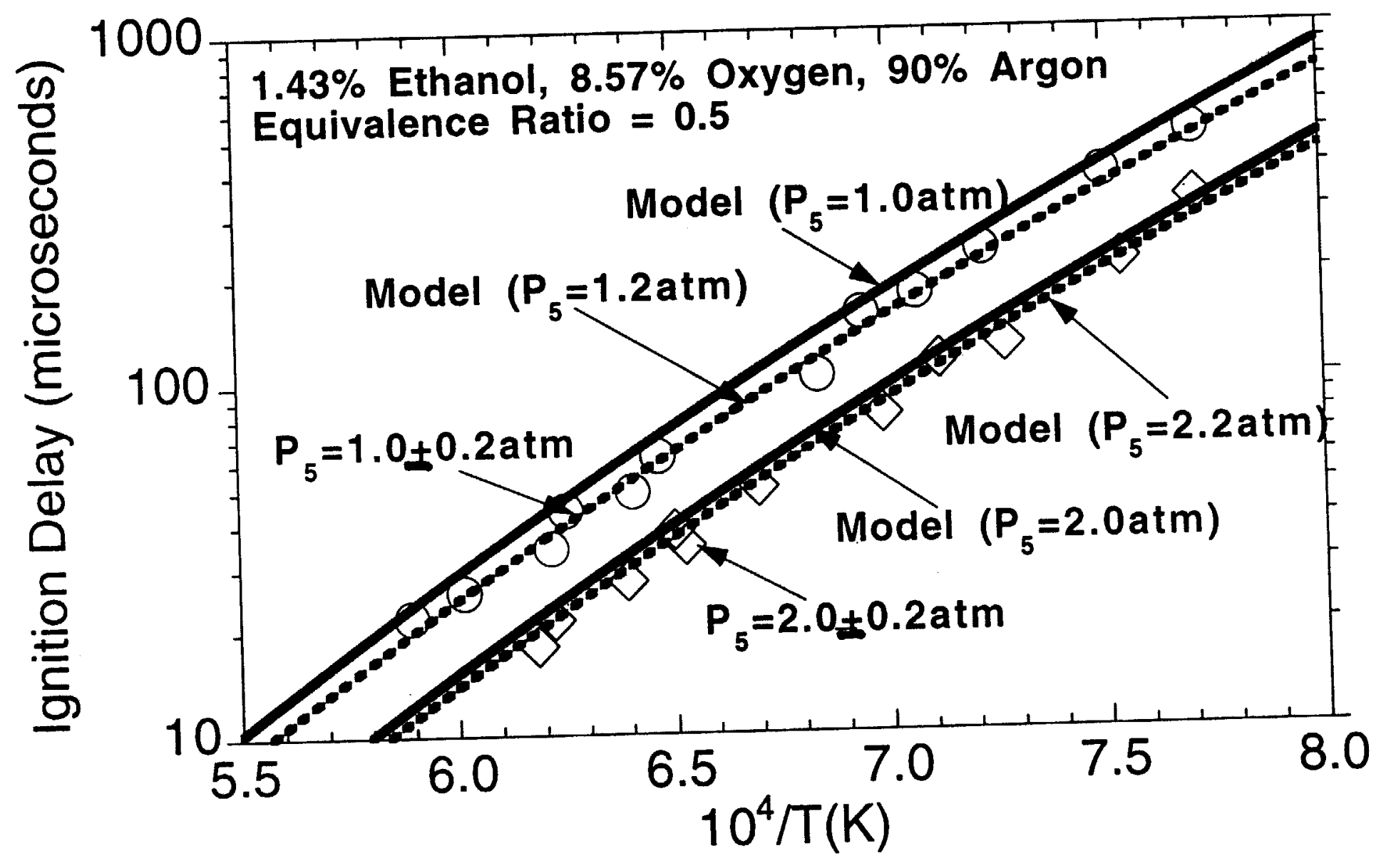

Fig. 2 


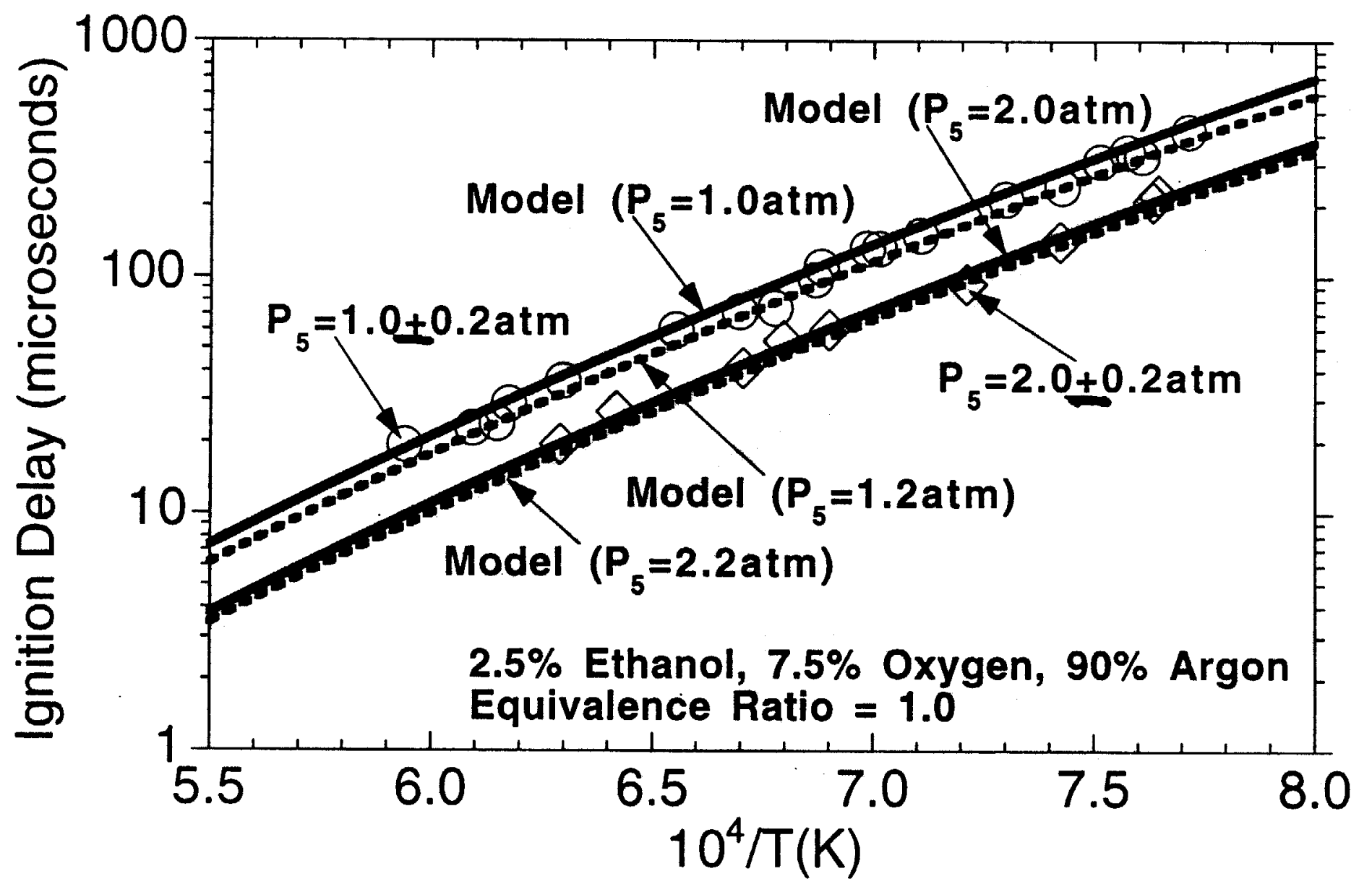

Fig. 3 


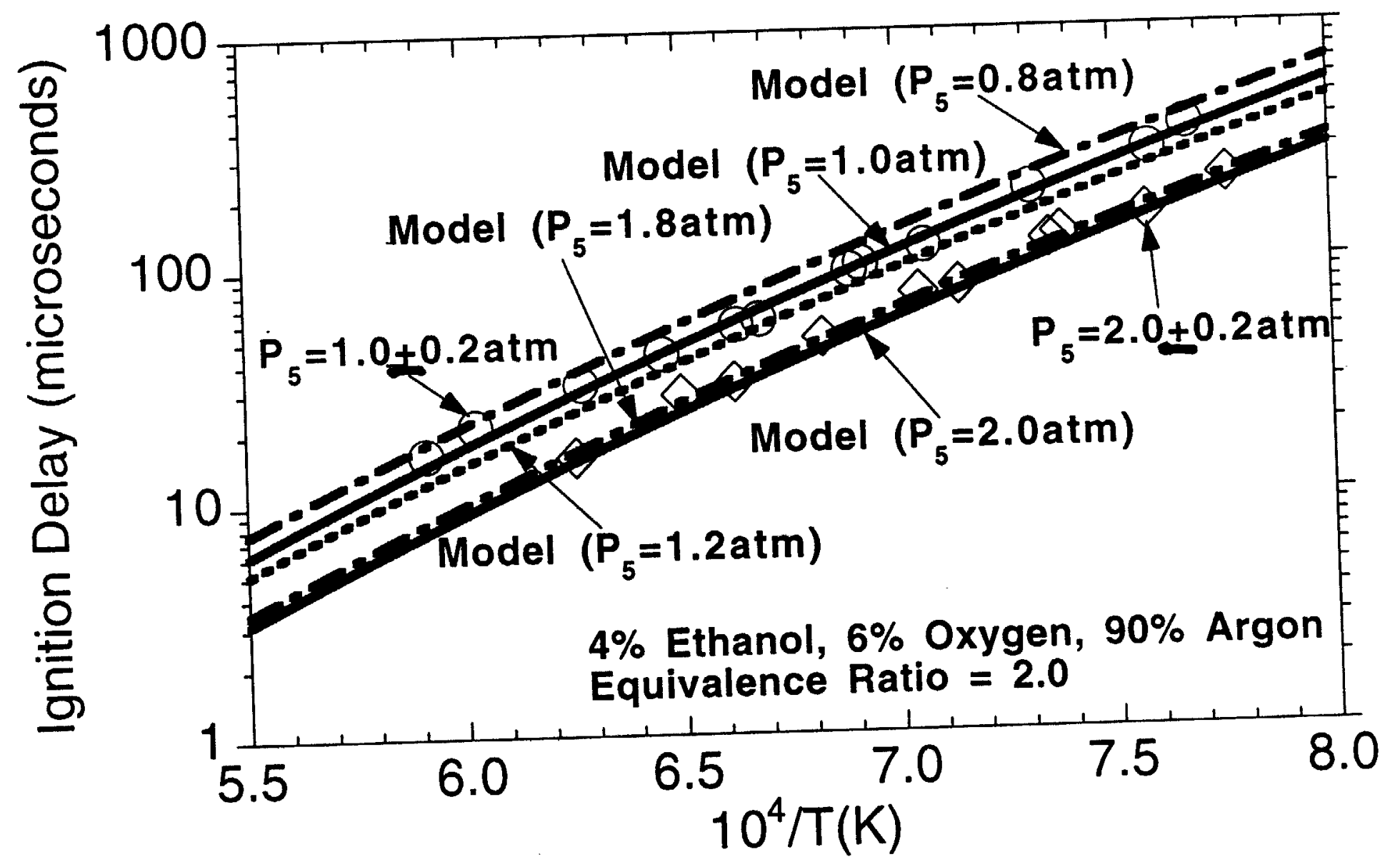

Fig. 4 


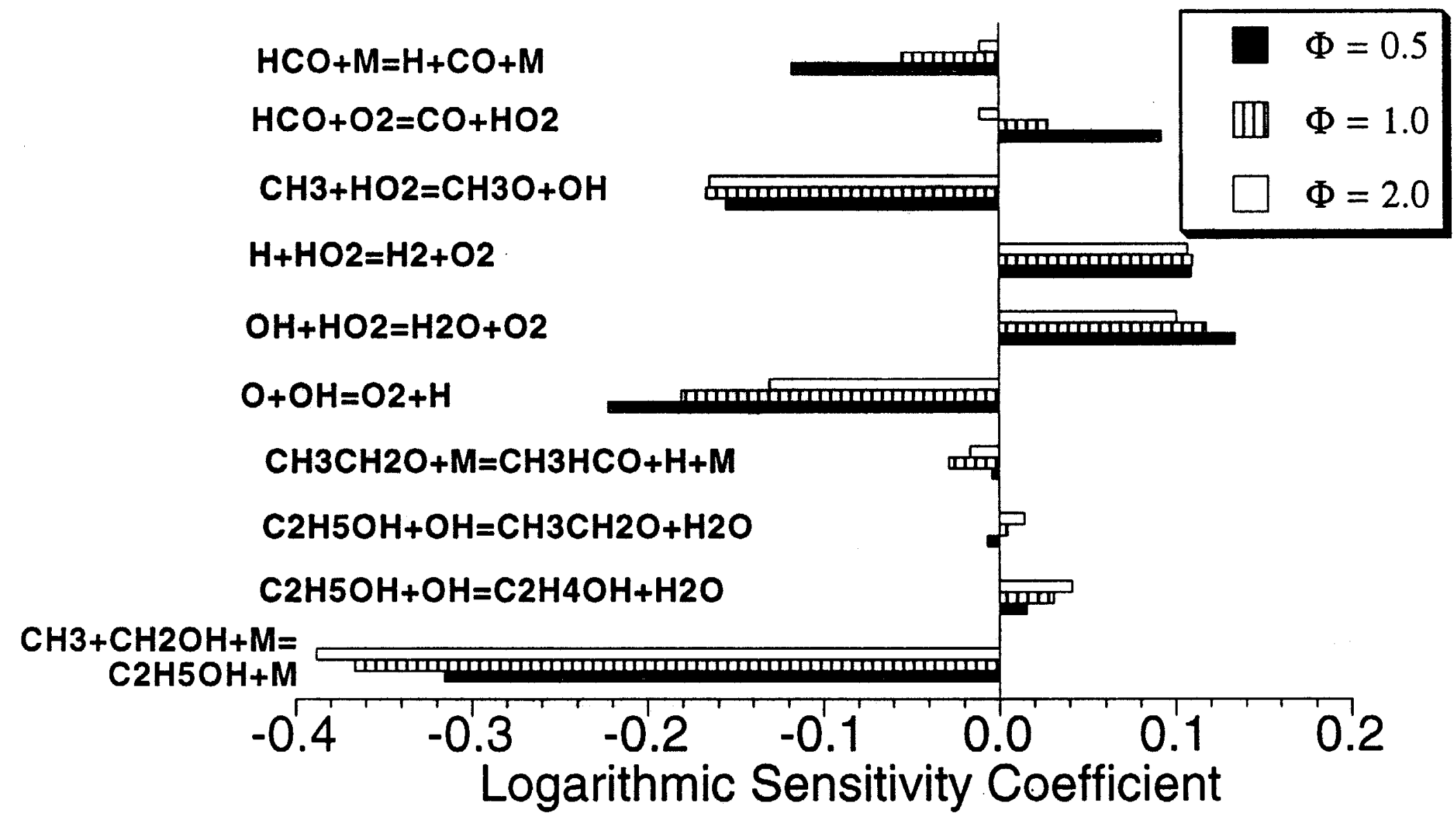

Fig. 5 


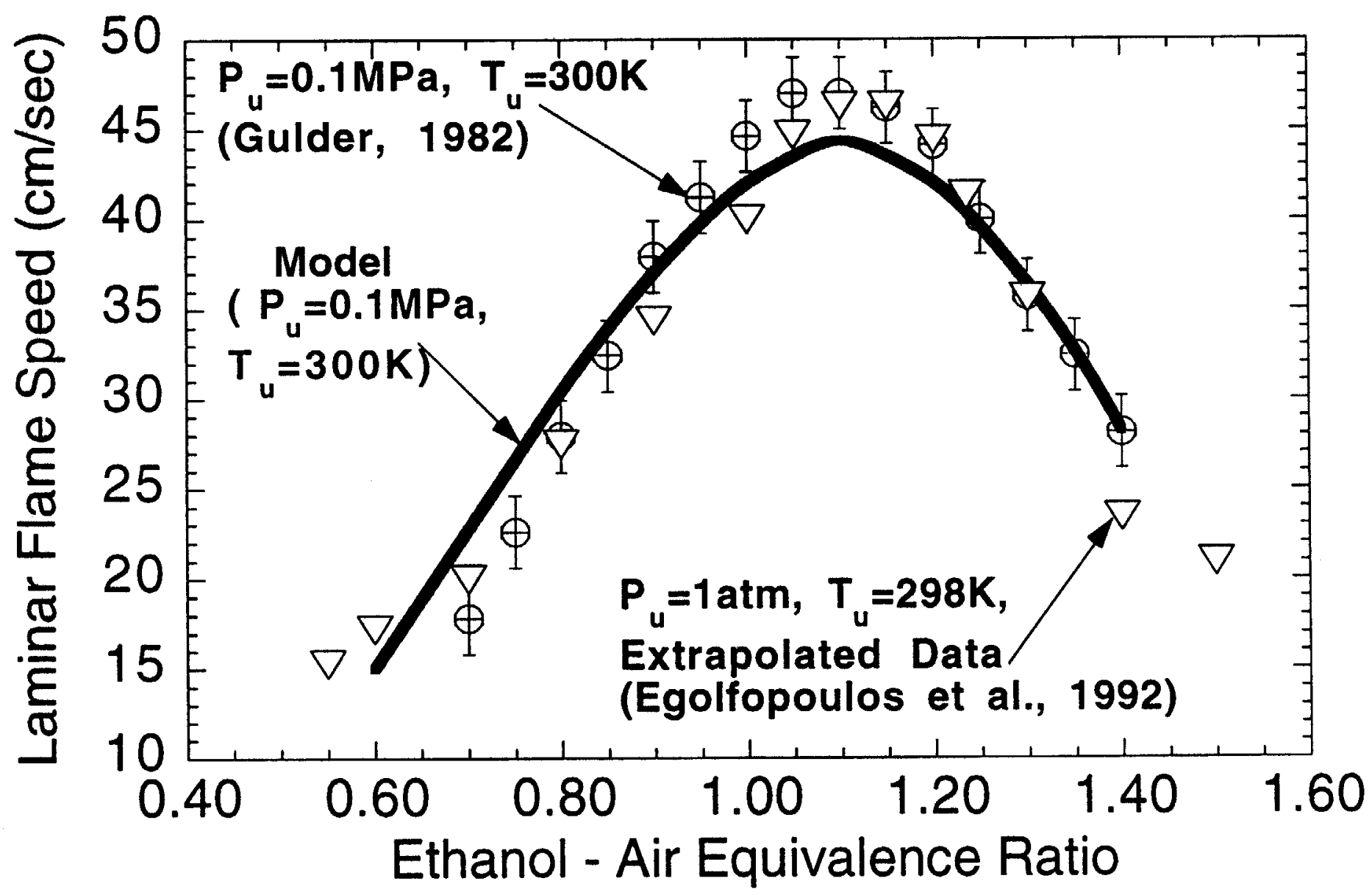

Fig. 6 


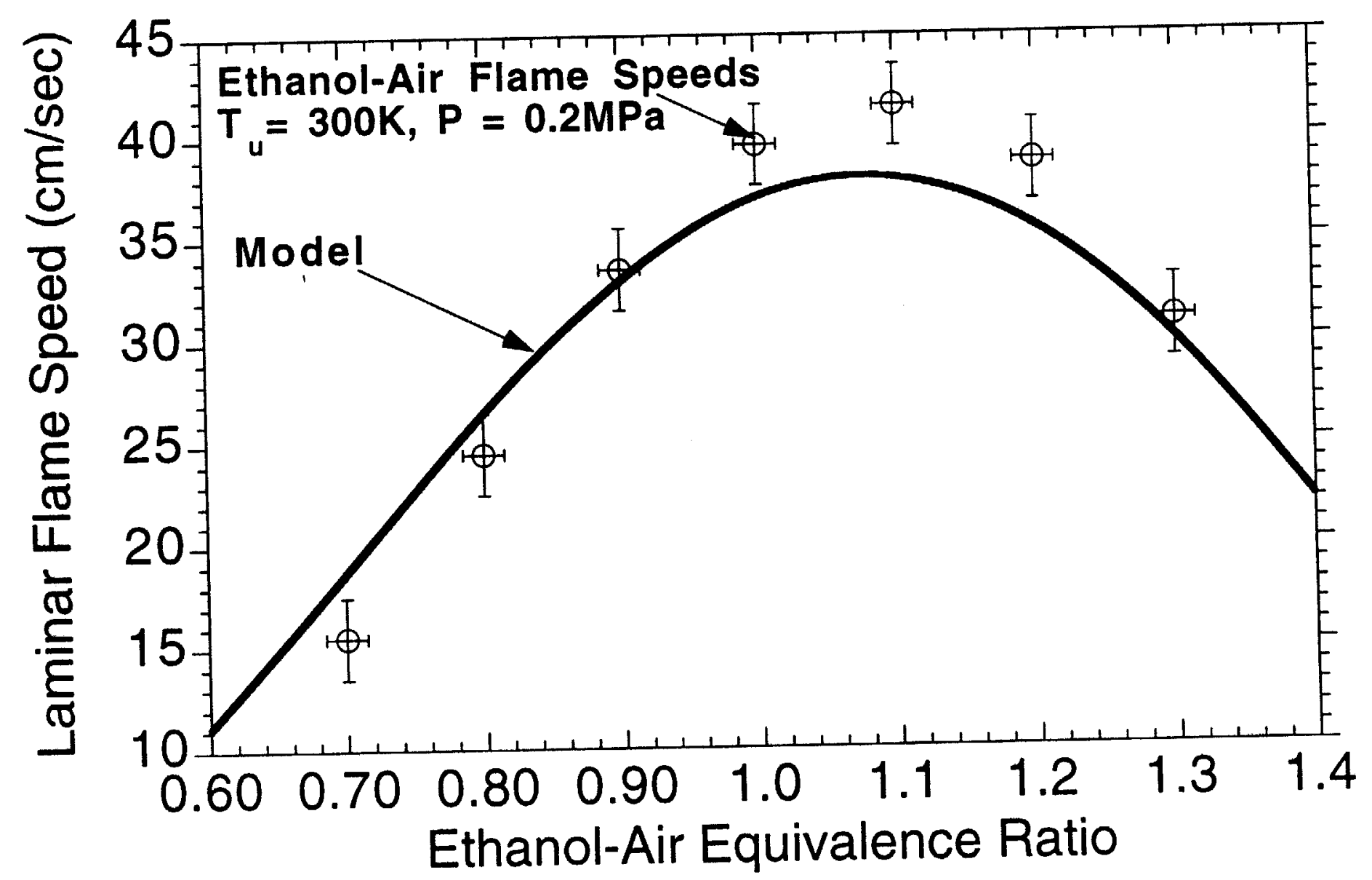

Fig. 7 


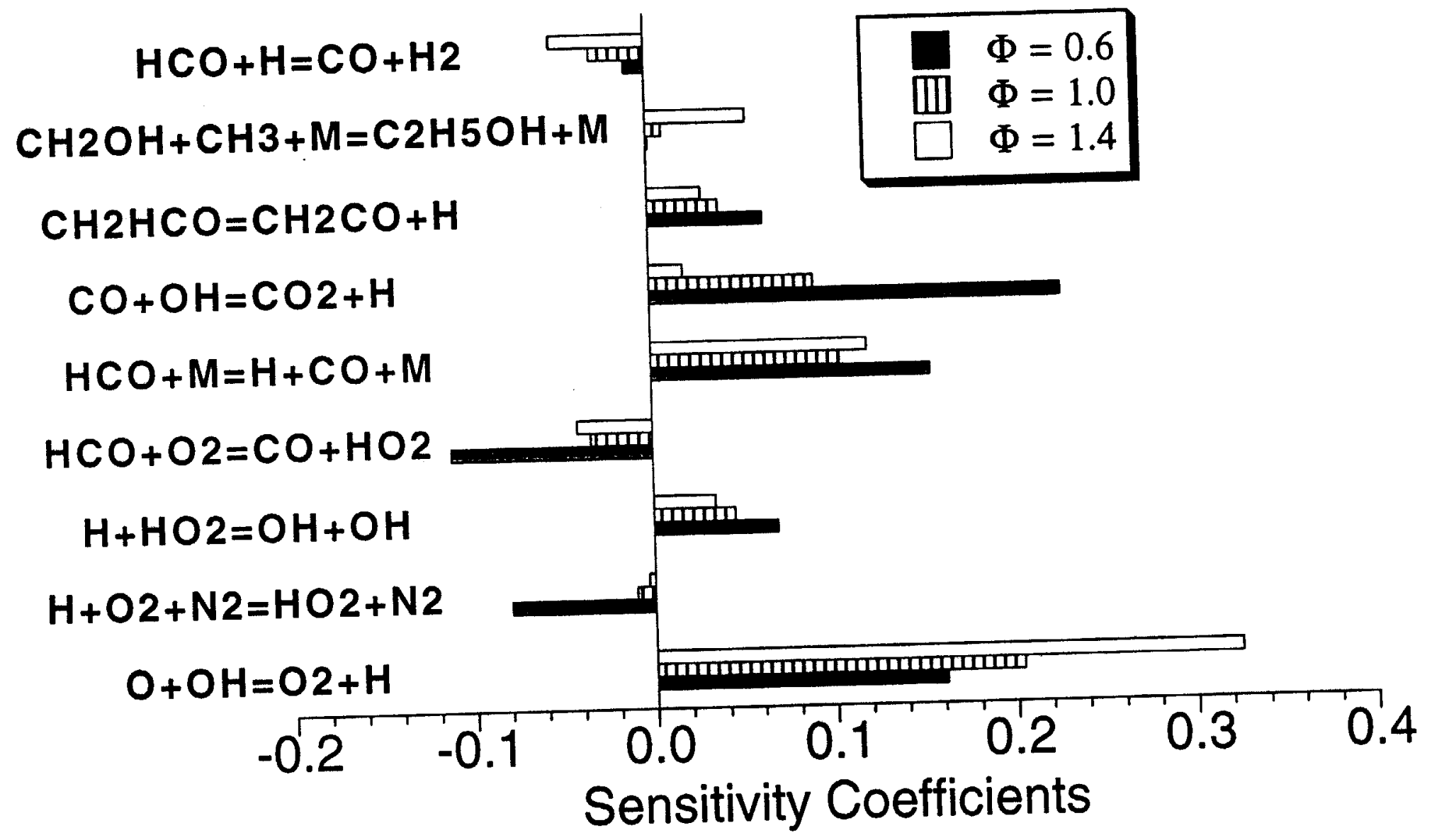

Fig. 8 


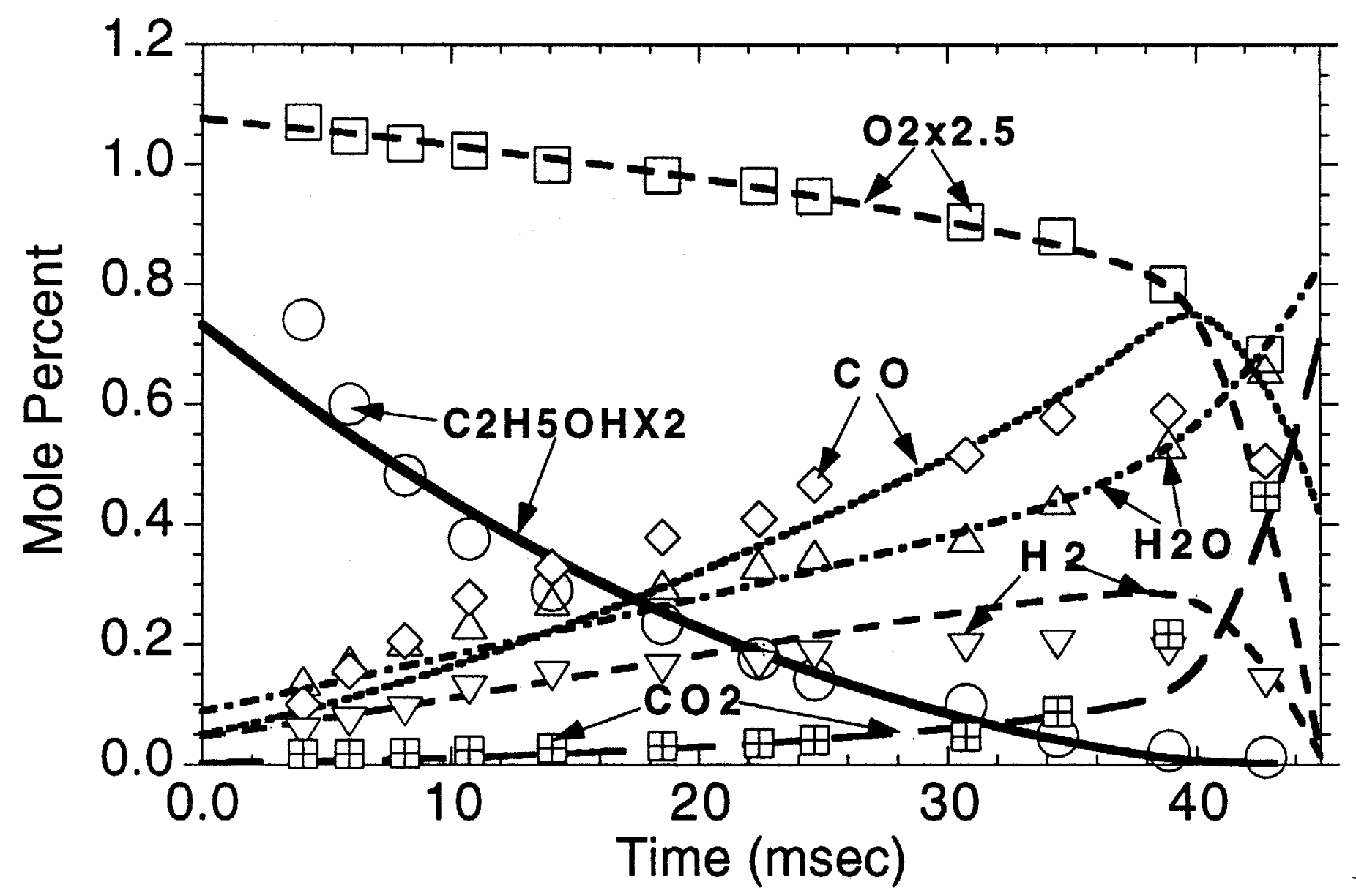

Fig. 9 


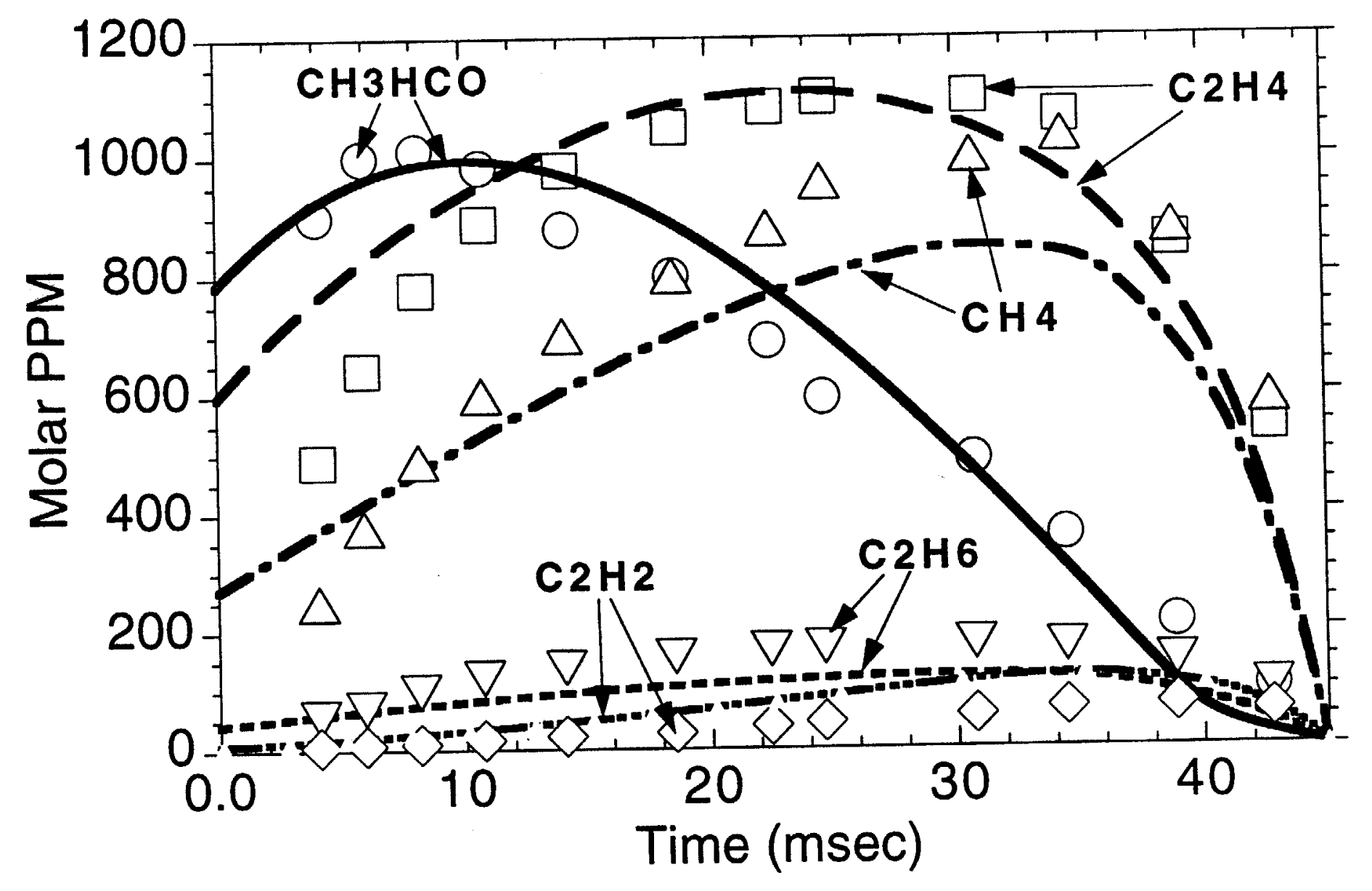

Fig. 10 
$11 \cdot 6.1 y$

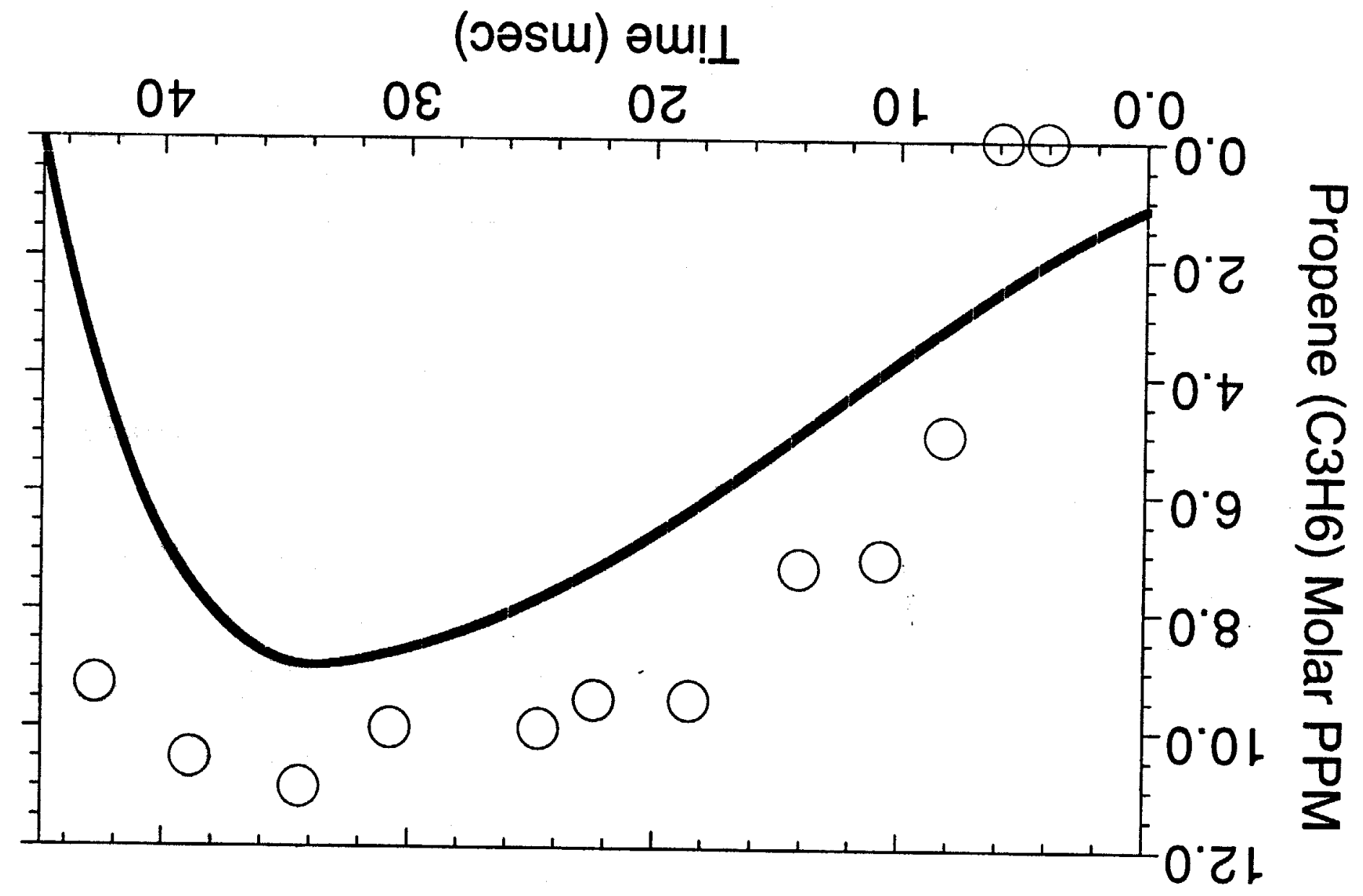




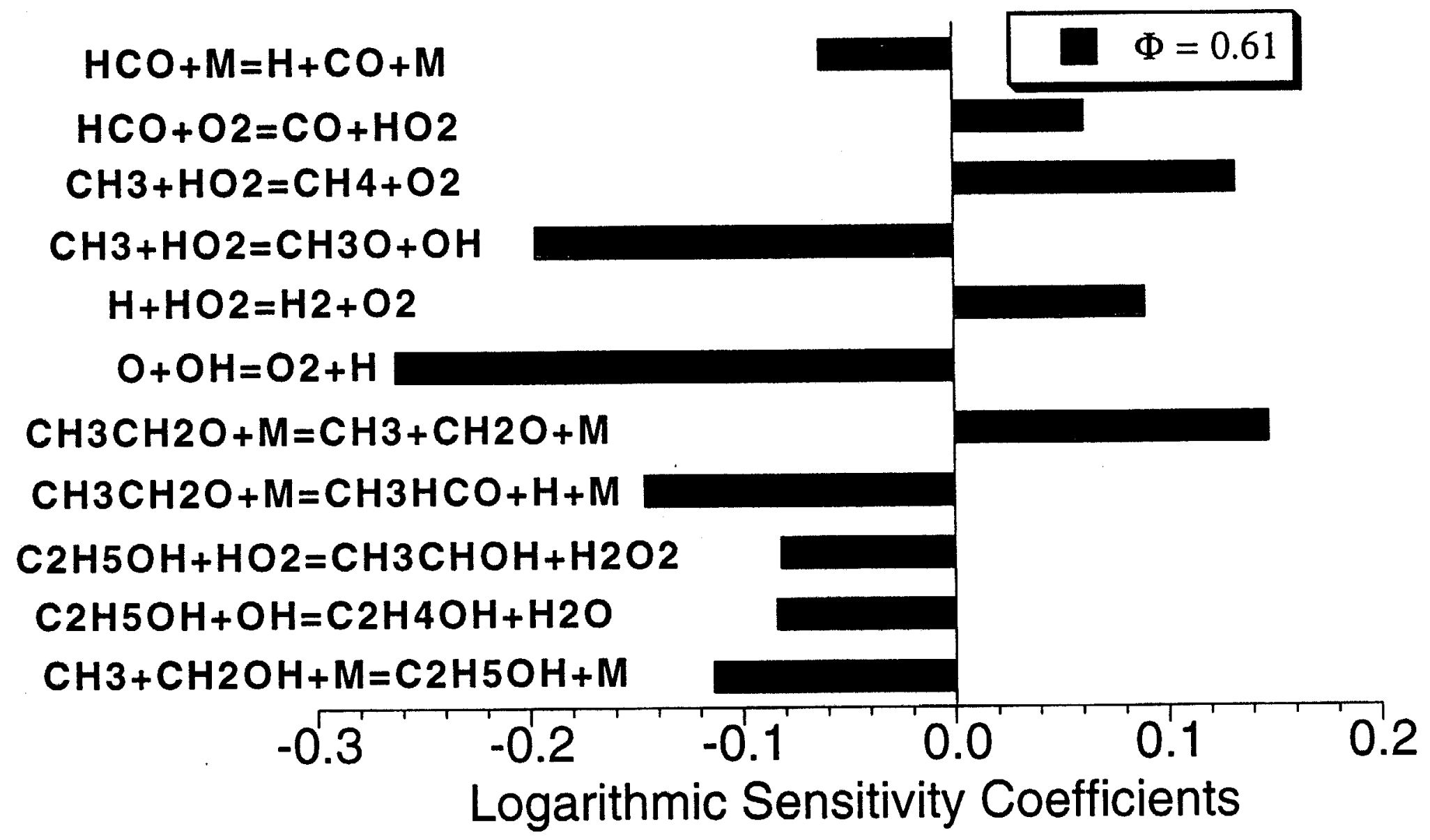

Fig. 12 


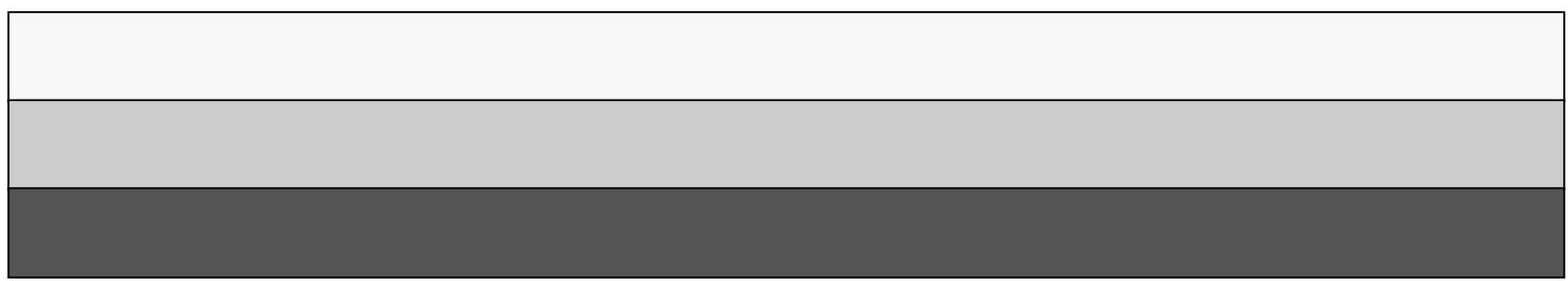

